\title{
Molecular detection of Bartonella spp. in terrestrial leeches (Haemadipsa rjukjuana) feeding on human and animal blood in Gageo-do, Republic of Korea
}

\author{
Jun-Gu Kang ${ }^{1 \dagger}$, Sohyun Won ${ }^{1 \dagger}$, Hye-Won Kim', Baek-Jun Kim², Bae-Keun Park ${ }^{3}$, Tae-Seo Park ${ }^{4}$, Hong-Yul Seo ${ }^{4}$ \\ and Joon-Seok Chae ${ }^{1 *}$
}

\begin{abstract}
Background: Leeches can transmit pathogens and are therefore potentially hazardous to human and animal health. However, only a few studies of diseases transmitted by land leeches have been reported. The purpose of the present study was to analyse which pathogens are carried in Haemadipsa rjukjuana, the first recorded sanguivorous land leech in the Republic of Korea (ROK).

Findings: A total of 173 H. rjukjuana were collected from Mt. Dock-Sil on Gageo-do Island, ROK during July 2011. Conventional PCR was conducted for analysis of the origin of blood meal, as well as for detection of species of Anaplasma, Bartonella, Borrelia, Ehrlichia, Rickettsia, and Wolbachia in the leech specimens. Bartonella DNA was detected in eight of the specimens studied based on partial ITS sequence analysis. Seven of the DNA samples were closely related to Bartonella grahamii (99.6-100\% similarity), and one sample exhibited a $90.6 \%$ similarity with Bartonella sp. from Taiwan. Sequences of the mitochondrial cytochrome $b$ gene were generated for a total of 35 of the 173 leech internal organ samples. These included sequences of human $(n=10)$, mouse $(n=8)$, weasel $(n=6)$ and bird $(n=11)$ origin. Of these 35 sequences, $68.5 \%$ were from mammals, including humans, and $31.4 \%$ were from migratory birds that pass through Gageo-do, ROK.
\end{abstract}

Conclusions: Although the present study does not provide evidence that leeches indeed transmit Bartonella species to hosts directly, to our knowledge this is the first report on Bartonella DNA being detected from leeches. Therefore, further studies are needed to explore the possibility of zoonotic pathogen transmission by land leeches.

Keywords: Bartonella grahamii, Haemadipsa rjukjuana, Land leech, Host origin, PCR, Republic of Korea

\section{Background}

The possibility that leeches can be vectors of pathogens has been studied in the more recent past, especially with the advent of leech therapy. The medical leech, Hirudo medicinalis may bring about severe diseases by transmitting infectious agents that cause syphilis (Treponema pallidum), erysipelas (Streptococcus sp.), tetanus

\footnotetext{
* Correspondence: jschae@snu.ac.kr

${ }^{\dagger}$ Equal contributors

'Laboratory of Veterinary Internal Medicine, BK21 PLUS Program for Creative Veterinary Science Research, Research Institute for Veterinary Science and College of Veterinary Medicine, Seoul National University, Seoul 08826, South Korea

Full list of author information is available at the end of the article
}

(Clostridium tetani), hog cholera (hog-cholera virus), and hospital wound infection (Aeromonas hydrophila) [1-4]. Besides medical leeches, there are reports that Ozobranchus (turtle leech) may be a mechanical vector for the fibropapilloma-associated turtle herpesvirus [5] and that Rickettsia infection was detected in Torix tagoi, Torix tukubana and Hemiclepsis marginata [6]. These reports suggest that various live bacteria or viruses can remain in the gut of leeches. Although leeches are potentially hazardous to human health, the number of previous studies surveying diseases transmitted by these segmented worms is very limited [7]. Because the blood remaining in the leeches can be 
detected by polymerase chain reaction (PCR), this method has recently been used to monitor the biodiversity of terrestrial mammals that are blood meal to these worms. Thus PCR is a useful tool for understanding the feeding habits of leeches [8].

In previous studies, Haemadipsa rjukjuana (Hirudiniformes: Haemadipsidae) was identified as the first reported sanguivorous land leech in the Republic of Korea (ROK) $[9,10]$. Members of the Haemadipsidae are known for their affinity to vertebrate blood [11]. In this study, a survey of prevalent pathogens in $H$. rjukjuana and of its blood meal was conducted by PCR assay. The terrestrial leeches were screened for the presence of Anaplasma phagocytophilum, Anaplasma bovis, Ehrlichia chaffeensis, Ehrlichia canis, Borrelia burgdorferi, Bartonella spp., Rickettsia spp. and Wolbachia spp. DNA by using a set of species-specific primers. For blood meal screening, the mitochondrial cytochrome $b$ gene was used to amplify host blood DNAs from the internal organs of $H$. rjukjuana collected in the field.

\section{Methods}

A total of 173 terrestrial leeches were collected at Mt. Dock-Sil (altitude $639 \mathrm{~m}, 34^{\circ} 04^{\prime} \mathrm{N}, 125^{\circ} 07^{\prime} \mathrm{E}$ ) in Gageo-do (Island), Shinan-gun, Jeollanam-do (Province), ROK (Fig. 1) during July 2011. The collection of leeches was conducted by walking along the forest path to attract the leeches and those that attached to the shoes or socks were removed by tweezers as soon as possible. The land leeches were preserved in $70 \%$ ethanol for genomic DNA extraction, which was performed with the DNeasy Blood \& Tissue Kit (Qiagen, Hilden, Germany) according to the manufacturer's instructions and stored at $-20{ }^{\circ} \mathrm{C}$. For the detection of zoonotic pathogens, the 16S-23S internal transcribed spacer (ITS) region of Bartonella spp., A. phagocytophilum, A. bovis, E. chaffensis, E. canis, B. burgdorferi, Rickettsia spp. and Wolbachia spp. were PCR amplified. For analysis of the host animals, the mitochondrial DNA cytochrome $b$ gene was amplified by conventional PCR. The primers used for PCR amplification are listed in Table 1. PCR products were separated by electrophoresis in $1.5 \%$ agarose gels and visualised by ethidium bromide staining. The amplicons were analysed by direct sequencing. The GenBank accession numbers of the ITS sequences related to Bartonella spp. are shown in Fig. 2. The phylogenetic relationships between haplotypes were reconstructed using the neighbor-joining method under the Maximum Composite Likelihood model. Confidence in the estimated relationship was determined using the bootstrap approach obtained through 1,000 replicates with the same model as mentioned above. Both the bootstrap analysis and the phylogeny reconstruction were conducted using MEGA version 6 [12].

\section{Results}

The PCR amplification of the partial ITS sequences resulted in detection of Bartonella spp. from 8 of the 173 leech specimens. Of these, seven samples were closely related to Bartonella grahamii with 99.6-100 \% sequence similarity and one sample exhibited a $90.6 \%$ similarity with Bartonella sp. KM2563 (FJ667565) from a wild rodent in Taiwan. Among the seven B. grahamii sequences, two were closest to B. grahamii KWDBG 41 (JN810847, ROK) from Apodemus agrarius (99.6-100\% similarity, respectively), and the other five samples were identical with B. grahamii V2 (AJ269785). As a result, the sequences of $B$. grahamii obtained in this study were divided into two sub-clades. One sub-clade included the V2 isolate from the United Kingdom (AJ269785) and one Korean genotype (JN810847) and the other sub-clade included another Korean genotype (JN810843) (Fig. 2). These results suggest that $B$. grahamii may have two different strains existing in the ROK.
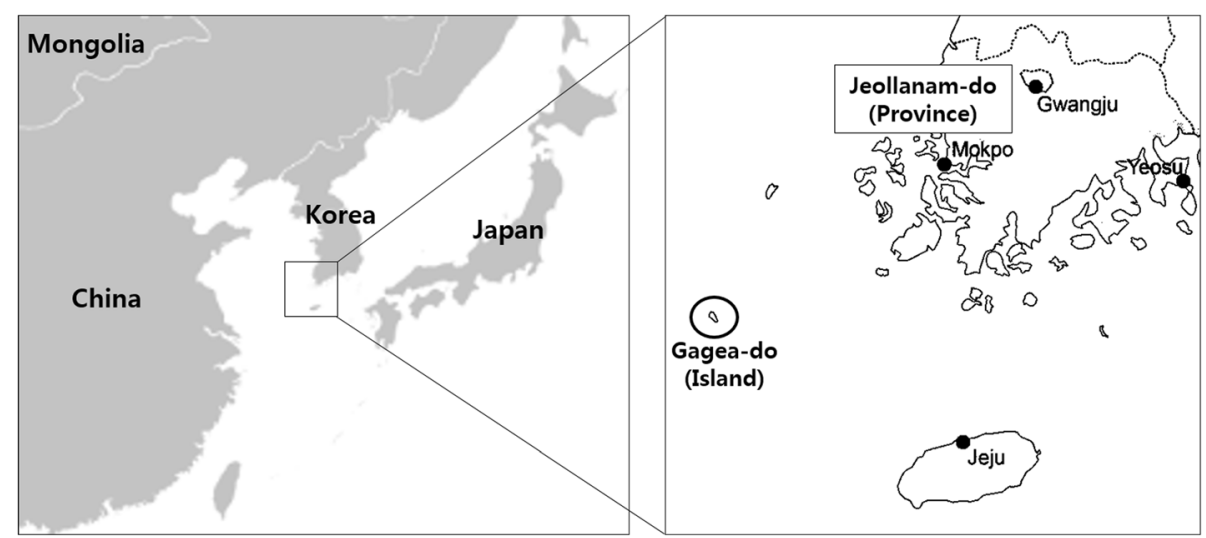

Fig. 1 Map of Gageo-do Island in the Republic of Korea. Gageo-do (black circle) is at Shinan-gun, Jeollanam-do Province and Korea's south-westernmost island. Leeches were collected from the mountain Dock-Sil in Gageo-do 
Table 1 Nucleotide sequences of polymerase chain reaction primers and conditions used for amplification of Bartonella spp. and host genes from land leeches

\begin{tabular}{|c|c|c|c|c|c|c|}
\hline Target gene & PCR & $\begin{array}{l}\text { Name of the PCR } \\
\text { primer used }\end{array}$ & Sequence $\left(5^{\prime}-3^{\prime}\right)$ & $\begin{array}{l}\text { Annealing } \\
\text { temperature }\end{array}$ & $\begin{array}{l}\text { Amplicon } \\
\text { size (bp) }\end{array}$ & Reference \\
\hline \multirow[t]{4}{*}{ Bartonella spp. ITS } & \multirow[t]{2}{*}{$1^{\text {st }}$} & QHVE1 & TTCAGATGATGATCCCAAGC & \multirow[t]{2}{*}{58} & \multirow[t]{2}{*}{735} & \multirow[t]{4}{*}{ [21] } \\
\hline & & QHVE4 & AACATGTCTGAATATATCTTC & & & \\
\hline & \multirow[t]{2}{*}{$2^{\text {nd }}$} & QHVE12 & CCGGAGGGCTTGTAGCTCAG & \multirow[t]{2}{*}{58} & \multirow[t]{2}{*}{484} & \\
\hline & & QHVE14 & CACAATTTCAATAGAAC & & & \\
\hline \multirow[t]{2}{*}{ Anaplasma spp.16S rRNA } & \multirow[t]{2}{*}{$1^{\text {st }}$} & $A E 1-F$ & AAGCTTAACACATGCAAGTCGAA & \multirow[t]{2}{*}{56} & \multirow[t]{2}{*}{1,406} & \multirow[t]{4}{*}{ [21] } \\
\hline & & AE1-R & AGTCACTGACCCAACCTTAAATG & & & \\
\hline \multirow[t]{2}{*}{ Anaplasma phagocytophilum $16 \mathrm{~S}$ rRNA } & \multirow[t]{2}{*}{$2^{\text {nd }}$} & EE3 & GTCGAACGGATTATTITTATAGCTTGC & \multirow[t]{2}{*}{56} & \multirow[t]{2}{*}{926} & \\
\hline & & EE4 & CCCTTCCGTTAAGAAGGATCTAATCTCC & & & \\
\hline \multirow[t]{2}{*}{ Anaplasma bovis $16 \mathrm{~S}$ rRNA } & \multirow[t]{2}{*}{$2^{\text {nd }}$} & ABkf & TAGCTTGCTATGGGGACAA & \multirow[t]{2}{*}{59} & \multirow[t]{2}{*}{547} & \\
\hline & & ABlr & TCTCCCGCACTCCAGTCTG & & & \\
\hline \multirow[t]{2}{*}{ Ehrlichia spp. 16S rRNA } & \multirow[t]{2}{*}{$1^{\text {st }}$} & ECC & AGAACGAACGCTGGCGGCAAGC & \multirow[t]{2}{*}{56} & \multirow[t]{2}{*}{450} & \multirow[t]{6}{*}{ [22] } \\
\hline & & ECB & CGTATTACCGCGGCGCTGGCA & & & \\
\hline \multirow[t]{2}{*}{ Ehrlichia chaffeensis $16 \mathrm{~S}$ rRNA } & \multirow[t]{2}{*}{$2^{\text {nd }}$} & HE3 & TATAGGTACCGTACTTATCTTCCCTAT & \multirow[t]{2}{*}{56} & \multirow[t]{2}{*}{390} & \\
\hline & & HE1 & CAATTGCTTATAACCCTITTGGTTATAAAT & & & \\
\hline \multirow[t]{2}{*}{ Ehrlichia canis $16 \mathrm{~S}$ rRNA } & $2^{\text {nd }}$ & HE3 & TATAGGTACCGTACTTATCTTCCCTAT & 56 & 365 & \\
\hline & & ECAN5 & CAATTATTTATAGCCTCTGGCTATAGGC & & & \\
\hline Borrelia burgdoferi $16 \mathrm{~S}$ rRNA & $1^{\text {st }}$ & B1 & CAGTGCGTCTTAAGCATGC & 59 & 1,427 & [21] \\
\hline & & B8 & ССТTAAATACСТTСТССC & & & \\
\hline & $2^{\text {nd }}$ & B3 & GCAGCTAAGAATCTTCCGCAATGG & 60 & 714 & \\
\hline & & B6 & CAACCATGCAGCACTGTATAT & & & \\
\hline Rickettsia sp. gltA & $1^{\text {st }}$ & RpCS. 877p & GGGGACCTGCTCACGGCGG & 54 & 382 & [23] \\
\hline & & RpCS. 1258n & ATTGCAAAAAGTACAGTGAA & & & \\
\hline & $2^{\text {nd }}$ & RpCS. 896p & GGCTAATGAAGCAGTGATAA & 58 & 338 & \\
\hline & & RpCS. 1233n & GCGACGGTATACCCATAG & & & \\
\hline Wolbachia 165 rRNA & & $16 S-F$ & TTGTAGCCTGCTATGGTATAACT & 56 & 937 & [24] \\
\hline & & $16 S-R$ & GAATAGGAGTITTCATGT & & & \\
\hline mt DNA cytochrome $b$ gene & & L14841 & AAAAAGCTTCCATCCAACATCTCAGCATGATG & 50 & 450 & [25] \\
\hline & & H15149 & AAACTGCAGCCCCTCAGAATGATATTTGTCCTCA & & & \\
\hline
\end{tabular}

With regard to the mitochondrial DNA cytochrome $b$ gene analysis to identify host animals, a total of 35 sequences were obtained from the 173 leech samples. The rest of the samples were not amplified or proved to be of other species. Of the 35 amplicons analysed, human $(n=10)$, mouse $(n=8)$, weasel $(n=6)$, pale thrush $(n=3)$, grey-backed thrush $(n=3)$, rufous-tailed robin $(n=1)$, Siberian rubythroat $(n=1)$, oriental magpie robin $(n=1)$, black-faced bunting $(n=1)$ and yellowthroated bunting $(n=1)$ DNA sequences were detected (Table 2). About $68.5 \%$ of the sequences were mammalian, including human, in origin, and about $31.4 \%$ were from migratory birds that pass through Gageo-do Island. Only a single DNA sequence of weasel origin was detected from leeches positive for Bartonella spp.

\section{Discussion}

Most vector-borne diseases, including dengue, Lyme disease, malaria, endemic typhus, and bartonellosis are transmitted by sucking arthropods such as fleas, mosquitoes and ticks [13]. Leech is also a haematophagous ectoparasite, sucking the blood of humans and animals such as fishes, frogs, turtles and birds. The process of digestion of the ingested blood is very slow so that the blood can remain in the leech gut for up to 27 weeks [7, 14]. In fact, researchers have recently suggested that leeches might be promising candidates as vectors [8]. Reports have been published on infection of leeches by Streptococcus spp., Clostridium tetani, classical swine fever virus, Aeromonas hydrophila, bovine parvovirus, feline calicivirus, equine arteritis virus, equine herpesvirus type 1 , and Rickettsia spp. [1-4, 7]. In 


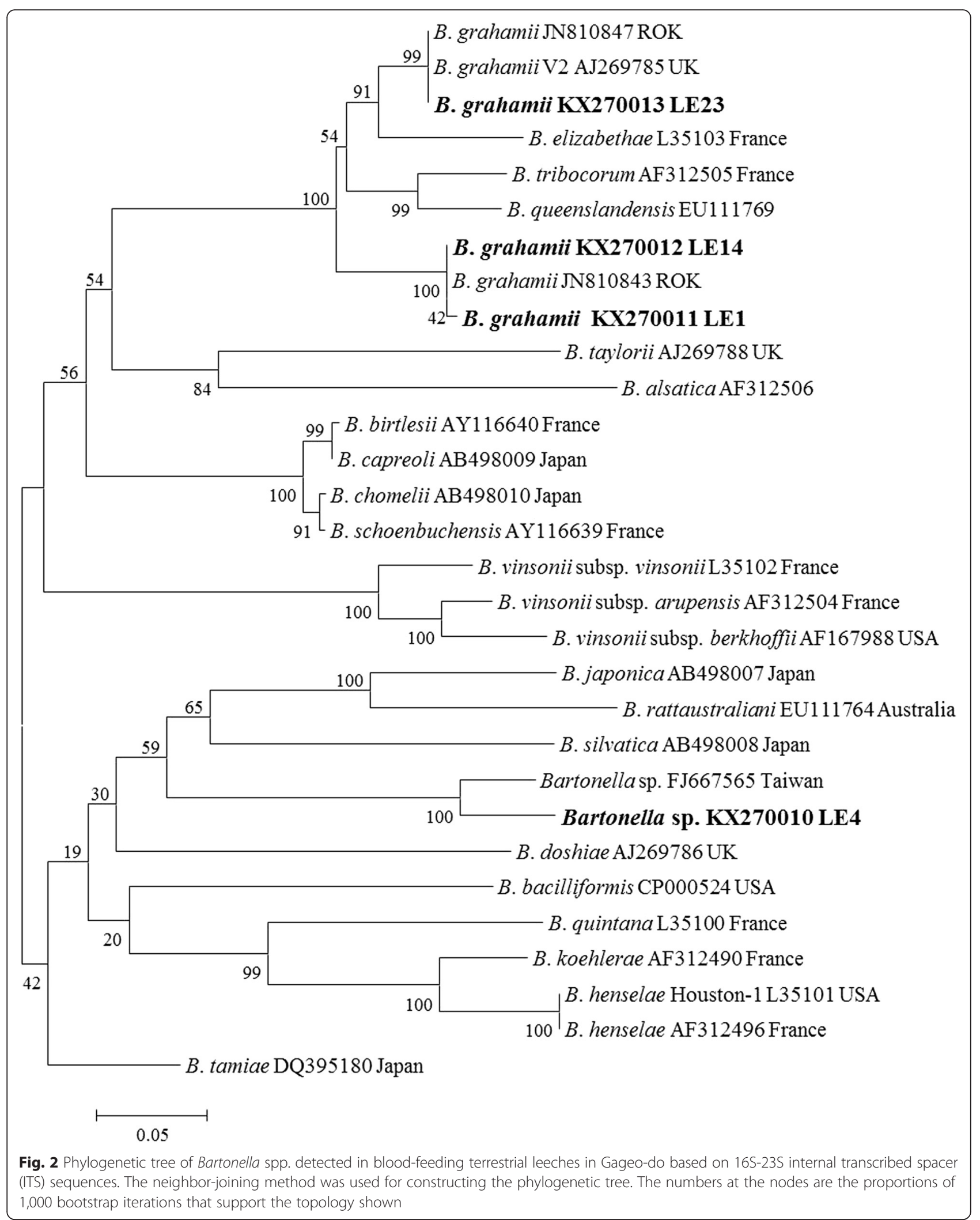


Table 2 Detection of host genes using mtDNA cytochrome $b$ gene from land leeches

\begin{tabular}{llll}
\hline Detected hosts & Scientific names & Category & No. of identified samples \\
\hline Human & Homo sapiens & Mammal & 10 \\
Mouse & Mus musculus & Mammal & 8 \\
Weasel & Mustela sibirica & Mammal & 6 \\
Pale ouzel & Turdus pallidus & Bird & 3 \\
Grey-backed thrush & Turdus hortulorum & Bird & 3 \\
Rufous-tailed robin & Luscinia sibilans & Bird & 1 \\
Siberian rubythroat & Luscinia calliope & Bird & 1 \\
Oriental magpie robin & Copsychus saularis & Bird & 1 \\
Black-faced bunting & Emberiza spodocephala & Bird & 1 \\
Yellow-throated bunting & Emberiza elegans & Bird & 1 \\
Total & & & 35
\end{tabular}

the present study, both Bartonella sp. and B. grahamii were detected from DNA extracted from the leeches, with a total infection rate of $4.6 \%(n=8 / 173)$. The 16S-23S ITS region of Bartonella spp. was chosen for the PCR amplification, being a useful genetic marker to identify this species because of its hyper-variable sequences and much lower sequence similarity than other target genes [15].

Bartonella spp. are small, gram-negative bacteria that infect red blood cells and invade endothelial cells, and are infective to hosts or reservoirs. Several Bartonella spp. are identified as zoonotic agents causing cat scratch disease, bacillary angiomatosis, neuroretinitis, etc. [16]. Because most of the species of Bartonella have been detected or cultured from numerous arthropods, various arthropods have been explored as potential vectors for this bacterial species [17], with ticks being a representative example considering some recent reports providing evidence that Ixodes ricinus may serve as a competent vector for Bartonella spp. suggesting a potential new vector $[18,19]$. However, its biological role has to be further investigated.

Bartonella spp. also have a natural cycle that comprises a vector and a host as other pathogens. Although our data was only represented the molecular evidence of Bartonella in leeches, we think that leech may serve as a host for Bartonella species. In addition to the record of Bartonella spp., a study of the blood meal is very important toward understanding the host preferences and vector capacity of leeches. Furthermore, blood meal is commonly used to investigate the distribution of hosts and to control disease spreading $[8,20]$. In the present study, human, mouse, weasel and bird DNA was detected from the terrestrial leeches inhabiting Mt. Dock-Sil (Table 2). Additionally, one DNA sample of weasel origin was identified from a leech positive for B. grahamii. This finding indicates that these leeches are likely to carry the blood of animals and thereby disperse several pathogens.
Because Gageo-do is an isolated island far from the mainland (Fig. 1), the mammalian fauna on the island is very sparse. Although only a few mammal species were detected as hosts in the blood meal, many bird species were evident. Gageo-do is known as a major stopover location for migratory birds that pass through the Yellow Sea; hence, the bird species detected in this study are all migratory birds that fly in from the north. Recently, the faunal distribution has been greatly influenced by rapid climate change, increasing the chance of inflow of new vectors and diseases. Blood meal screening could track the change of migratory birds that stop over at Gageo-do as well as their current distribution.

Our study provided new data on the potential role leeches may play in Bartonella spp. transmission. Although it does not prove that leeches indeed transmit the bacteria to the hosts, to our knowledge, this is the first report of Bartonella DNA being detected from leeches. The vector competence is completed when the zoonotic agent is transferred from the vector to the host reliably, and vertical or horizontal transmission should be possible $[6,17]$. Therefore, further studies are needed to prove the transmission of zoonotic pathogens by land leeches.

\section{Abbreviations}

DNA, deoxyribonucleic acid; ITS, internal transcribed spacer; PCR, polymerase chain reaction; $\mathrm{ROK}$, Republic of Korea

\section{Funding}

This work was supported by the National Institute of Biological Resources (1800-1844-301-260), Korea.

Availability of data and material

Not applicable.

Authors' contributions

JG Kang, S Won and JS Chae conceived the study design and drafted the manuscript. HW Kim, BK Park, and TS Park contributed in sample collection and manuscript preparation. BJ Kim and HY Seo contributed in sample 
collection and reviewed the manuscript. All authors read and approved the final version of the manuscript.

\section{Competing interests}

The authors declare that they have no competing interests.

\section{Consent for publication}

Not applicable.

\section{Ethics approval and consent to participate}

Not applicable.

\section{Author details}

${ }^{1}$ Laboratory of Veterinary Internal Medicine, BK21 PLUS Program for Creative Veterinary Science Research, Research Institute for Veterinary Science and College of Veterinary Medicine, Seoul National University, Seoul 08826, South Korea. ${ }^{2}$ National Institute of Ecology, 1210 Geumgang-ro, Maseo-myeon, Seocheon-gun, Choongcheongnam-do 33657, South Korea. ${ }^{3}$ College of Veterinary Medicine, Chungnam National University, Daejeon 306-764, South Korea. ${ }^{4}$ National Institute of Biological Resources, Incheon 404-708, South Korea

Received: 1 March 2016 Accepted: 30 May 2016

Published online: 07 June 2016

\section{References}

1. Adams SL. The medicinal leech. A page from the annelids of internal medicine. Ann Intern Med. 1988;109:399-405.

2. Dickinson MH, Lent CM. Feeding behavior of the medical leech, Hirudo medicinalis. L J Comp Physiol. 1984;154:449-55.

3. Kutschera U, Pfeiffer I, Ebermann E. The European land leech: biology and DNA-based taxonomy of a rare species that is threatened by climate warming. Naturwissenschaften. 2007:94:967-74.

4. Shope RE. The leech as a potential virus reservoir. J Exp Med. 1957;105:373-82.

5. Greenblatt RJ, Work TM, Balazs GH, Sutton CA, Casey RN, Casey JW. The Ozobranchus leech is a candidate mechanical vector for the fibropapillomaassociated turtle herpesvirus found latently infecting skin tumors on Hawaiian green turtles (Chelonia mydas). Virology. 2004;321:101-10.

6. Kikuchi Y, Fukatsu T. Rickettsia infection in natural leech populations. Microb Ecol. 2005;49:265-71.

7. Al-Khleif A, Roth M, Menge C, Heuser J, Baljer G, Herbst W. Tenacity of mammalian viruses in the gut of leeches fed with porcine blood. J Med Microbiol. 2011;60:787-92.

8. Schnell ID, Thomsen PF, Wilkinson N, Jensen LRD, Willerslev E, Bertelsen MF, Gilbert MTP. Screening mammal biodiversity using DNA from leeches. Curr Biol. 2012;2:R262-3.

9. Seo HY, Eun Y, Park TS, Kim KG, Won SH, et al. First record of blood-feeding terrestrial leech, Haemadipsa rjukjuana Oka, 1910 (Hirudinida: Arhynchobdellida: Haemadipsidae) in Korea. Korean J Soil Zool. 2013;17:14-8.

10. Won S, Park BK, Kim BJ, Kim HW, Kang JG, et al. Molecular identification of Haemadipsa rjukjuana (Hirudiniformes: Haemadipsidae) in Gageo Island. Korea Korean J Parasitol. 2014;52:169-75.

11. Borda, E. Systematics and biodiversity of Arhynchobdellida (Oligochaeta: Hirudinida) with a focus on the evolutionary history of blood-feeding terrestrial leeches. USA: ProQuest; 2007. p.9-26.

12. Tamura K, Stecher G, Peterson D, Filipski A, Kumar S. MEGA6: Molecular Evolutionary Genetics Analysis version 6.0. Mol Biol Evol. 2013;30:2725-9.

13. Gratz NG. Emerging and resurging vector-borne diseases. Ann Rev Entomol. 1999:44:51-75.

14. Saywer RT. Leech biology and behavior: feeding, biology, ecology and systematics v. 2. Oxford: Oxford University Press; 1986.

15. Gil H, Garcia-Esteban C, Barabdika JF, Peig J, Toledo A, et al. Variability of Bartonella genotypes among small mammals in Spain. Appl Environ Microbiol. 2010;76:8062-70.

16. Billeter SA, Levy MG, Chomel BB, Breitschwerdt EB. Vector transmission of Bartonella species with emphasis on the potential for tick transmission. Med Vet Entomol. 2008;22:1-15.

17. Anderson BE, Neuman MA. Bartonella spp. as emerging human pathogens. Clin Microbiol Rev. 1997;10:203-19.

18. Cotté V, Bonnet $\mathrm{S}$, Le Rhun D, Le Naour E, Chauvin A, et al. Transmission of Bartonella henselae by Ixodes ricinus. Emerg Infect Dis. 2008;14:1074-80.
19. Reis C, Cote M, Le Rhun D, Lecuelle B, Levin ML, et al. Vector competence of the tick Ixodes ricinus for transmission of Bartonella birtlesii. PLoS Negl Trop Dis. 2011;5:e1186.

20. Garlapati RB, Abbasi I, Warburg A, Poché D, Poché R. Identification of bloodmeals in wild caught blood fed Phlebotomus arhentipes (Diptera: Psychodidae) using cytochrome $b$ PCR and reverse line blotting in Bihar. India J Med Entomol. 2012:49:515-21.

21. Kang JG, Kim HC, Choi CY, Nam HY, Chae HY, et al. Molecular detection of Anaplasma, Bartonella, and Borrelia species in ticks collected from migratory birds from Hong-do Island, Republic of Korea. Vector Borne Zoonotic Dis. 2013;13:215-25.

22. Murphy GL, Ewing SA, Whitworth LC, Fox JC, Kocan AA. A molecular and serologic survey of Ehrlichia canis, E. chaffeensis, and E. ewingii in dogs and ticks from Oklahoma. Vet Parasitol. 1998;79:325-39.

23. Roux V, Rydkina E, Eremeeva M, Raoult D. Citrate synthase gene comparison, a new tool for phylogenetic analysis, and its application for the rickettsiae. Int J Syst Bacteriol. 1997;47:252-61.

24. O'Neill SL, Giordano R, Colbert AM, Karr TL, Robertson HM. 16S rRNA phylogenetic analysis of the bacterial endosymbionts associated with cytoplasmic incompatibility in insects. Proc Natl Acad Sci U S A. 1992;89:2699-702.

25. Folmer $\mathrm{O}$, Back M, Hoeh W, Lutz R, Vrijenhoek R. DNA primers for amplification of mitochondrial cytochrome c oxidase subunit I from diverse metazoan invertebrates. Mol Mar Biol Biotechnol. 1994:3:294-9.

\section{Submit your next manuscript to BioMed Central and we will help you at every step:}

- We accept pre-submission inquiries

- Our selector tool helps you to find the most relevant journal

- We provide round the clock customer support

- Convenient online submission

- Thorough peer review

- Inclusion in PubMed and all major indexing services

- Maximum visibility for your research

Submit your manuscript at www.biomedcentral.com/submit
Biomed Central 